1874, and his farm upbringing undoubtedly influenced his career. On leaving school he spent a short time in a bank; but farming was in his blood, and after attending classes at the University of Edinburgh, under Prof. Wallace, he went to Canada where, as a very young man, he became manager of a large ranch in Alberta.

On returning to Britain in 1897, Greig was appointed lecturer, first at Cheshire Agricultural College, and later at the Durham College of Science, Newcastleon-Tyne. In 1903 he married Maud, a daughter of the late Sir George Hunter of Newcastle. In the same year he went to the University of Aberdeen as Fordyce lecturer in agriculture, and during the next eight years took a leading part in building up the high reputation of the University Agricultural Department and the North of Scotland College of Agriculture.

In 1911 Greig was appointed inspector of agriculture under the Board of Education, but had scarcely taken up his duties when he was invited to become one of the three commissioners of the newly formed Board of Agriculture for Scotland, and in 1921 was made its chairman. In 1928, when the Board became the Department of Agriculture for Scotland, Sir Robert became its permanent secretary, and he held this post until he retired in 1934.

In the First World War he served with the Royal Scots in France, and was awarded the M.C. He was knighted in 1919. He held the honorary degrees of LL.D. (St. Andrews), and D.Sc.

Sir Robert travelled widely, visiting Canada, the United States, Australia, and various European countries on agricultural missions, and he was one of the British delegates to the Ottawa Conference. In 1929 he was president of Section M (Agriculture) of the British Association at its meetings in South Africa and, with Lady Greig and their daughter, visited Rhodesia and Kenya on the return journey. In the course of the tour he was in great demand to give talks to farmers and planters; I had the privilege of being with their party, and recall vividly the enthusiasm at these meetings.

During his official eareer, Sir Robert served on many important committees and councils, including the Carnegie Trust for the Universities of Scotland, of which he became chairman, the University Grants Committee, and the Agricultural Research Council. $\mathrm{He}$ was at one time chairman of the River Forth Conservancy Board, and was very active in the establishment of the Imperial Agricultural Bureaux, of which he became the first chairman. In 1940 he became chairman of a Scottish committee to encourage food production in private gardens and allotments, and devoted much time and energy to this work during the War.

Probably Sir Robert will be best remembered for his great services to agricultural education and research. During his period of office at the Department of Agriculture, no fewer than six research stations, now well known throughout the world, were set up in Scotland. These deal with animal nutrition, animal diseases, animal genetics, plant breeding, dairying, and soils, and their establishment was due, in great measure, to Sir Robert's foresight and enthusiasm for research. With the Macaulay Institute for Soil Research he had particularly close connexions, for he was a great personal friend of the founder, the late Mr. T. B. Macaulay, of Montreal, and he never spared himself in furthering the various schemes of agricultural betterment in Lewis and elsewhere in Scotland promoted by Mr. Macaulay. At the time of his death he was chairman of the council of management of the Macaulay Institute. His sincerity and profound knowledge of Scottish agriculture gained for him the respect and confidence of the farming community, and his friendship and encouragement meant a great deal to those of us who were closely associated with him.

When he retired at the age of sixty, Sir Robert was far too vigorous and active to settle down and do nothing. He became a director of the London, Midland and Scottish Railway, and one or two other companies, and threw himself with his usual zest into the new interests without, however, neglecting the old. Perhaps he overtaxed his strength and his death was unexpectedly sudden, but probably he would have wished it so.

It was something of a surprise to find Sir Robert was seventy-three when he died, for he remained so energetic and so youthful in spirit and appearance. His great personal charm and sense of humour made friends for him wherever he went, and those privileged to visit 'Shaws', his delightful home on the outskirts of Edinburgh, will always cherish memories of a charming host and a happy family circle. $\mathrm{He}$ is survived by Lady Greig, three sons and a daughter.

W. G. OGG

\section{Mr. H. W. Pugsley}

Herbert William Pugsley, the eminent amateur botanical systematist, died at Wimbledon on November 18. He was born at Bristol on January 24, 1868, and educated at the Grammar School there. At the age of seventeen he went to London to be coached for the Civil Service Examinations, and entered the Department of the Accountant-General of the Navy in 1886, where he remained until his retirement in 1928. After joining the Service he studied privately and obtained his B.A. degree of the University of London in 1889.

He was accustomed to spend his leave studying the floras of Great Britain and of central Europe, particularly of Switzerland, often in company with E. G. Baker and the late C. E. Salmon, who also accompanied him to North Africa in search of daffodils. Ever painstaking and critical, he soon became one of the leading British botanists-to use the general term for those engaged on the study of the flora. Of a quiet demeanour, he worked in close and friendly co-operation with the majority of his contemporaries, but had little patience with those whose identifications he considered slipshod-and occasionally said so.

Pugsley's first important work was on the British capreolate fumitories in 1902: he continued his interest in the genus, and published a monograph of Fumaria and Rupicapnos in 1919. He was also well known for his researches on Euphrasia, and his revision of the British Euphrasiece appeared in 1930. $\mathrm{He}$ was interested in narcissi and grew them in his garden for about fifty years : he wrote on the Poeticus group in 1915 and monographed the sub-genus $A j a x$ in 1933. Orchids had a continued fascination for him, and he wrote several papers on them, particularly the marsh orchids. The British robertsonian saxifrages also attracted him, and he revised the section in 1936. For many years he was engaged on a monograph of the British Hieracia. This, which he regarded as his magnum opus, is to be published by the Linnean Society, and the last batch of proofs 
was received during the week of his death. So far as I know, the only recognition of his work was the award of the William Herbert Medal of the American Amaryllis Society in 1940.

His manuscripts were a delight to edit-page after page of foolscap clearly written, with no alterations or erasures.

A little inclined in his later years to dilate on the investigation in hand, he was always willing to give what help he could, particularly to beginners : he was an excellent field naturalist.

He was a keen collector of water-colours, particularly of the Bristol School, and was a well-known frequenter of the sale rooms.

$\mathrm{He}$ had six sons, one of the surviving three being Prof. A. J. Pugsley, professor of civil engineering in the University of Bristol.

J. RAMSBOtTOM

\section{Prof. B. Bavink}

THE death occurred recently of Prof. Bernhard Bavink, an eminent German teacher of natural philosophy. His great work, "Ergebnisse und Probleme der exakten Naturwissenschaften", is internationally known. His last book, published in 1947, is entitled "Was ist Wahrheit in den exakten Naturwissenschaften?". He was one of the few men of science who never lost sight of the 'whole' while commanding very specialized knowledge of the sciences. His publications and lectures always attempted to bridge the gulf between modern, technically informed science and the sphere of faith and ethics and all the higher spiritual values. Bavink was born on June 30, 1879, in East Friesland. His last years were sad. A son of seventeen was called up towards the end of the War and was killed. An older son had been a prisoner of war in the U.S.S.R. and died from typhoid fever when he was just expected to go home. In the same year a daughter, lacking the necessary care and food, died of tuberculosis. At the time of his death, Prof. Bavink was on the point of taking a chair at the Stuttgart Technical College.

WE regret to announce the following deaths :

Dr. C. W. Kimmins, chief inspector of the Education Department, London County Council, during 1904-23 and president in 1929 of Section L (Educa. tion) of the British Association, on January 12, aged ninety-one.

Dr. John Marshall, reader in mathematics in the University of London (Bedford College), on January 16 , aged fifty-seven.

\section{NEWS and VIEWS}

\section{Geological Society: Awards}

THE council of the Geological Society has made the following awards: Wollaston Medal to Sir Edward Bailey, formerly director of the Geological Survey of Great Britain, in recognition of his researches on the mineral structure of the earth, especially the stratigraphy, structure and petrology of Scotland; Murchison Medal to Dr. J. Phemister, of the Geological Survey of Great Britain, in recog. nition of his important researches on the igneous and metamorphic rocks of the northern Highlands and his valuable contributions to petrology, mineralogy and geophysics; Lyell Medal to Prof. A. H. Cox, professor of geology at University College, Cardiff, for his researches, particularly on the stratigraphy and petrology of the Lower Palæozoic rocks of Wales; Prestwich Medal to the Abbé Henri Breuil, for his researches on the Quaternary, and especially for his investigations, begun in France, on the succession and correlation of Pleistocene deposits by their contained human artefacts; Wollaston Fund to Dr. J. G. C. Anderson, of the Geological Survey of Great Britain, in recognitıon of his researches on metamorphic and economic geology and particularly of his work on the Moine and Dalradian rocks of Scotland and Eire; Murchison Fund to Dr. F. W. Cope, of the Geological Survey of Great Britain, for his researches on the stratigraphy and palæontology of the Carboniferous rocks of Derbyshire and adjacent regions; Lyell Fund in two moieties to (1) Dr. Dorothy Rayner, lecturer in geology in the University of Leeds, for her outstanding work on the Mesozoic fishes, notably on the neurocranium, and relationships of the holosteans ; and (2) Mr. W. D. Ware, for his researches on Carboniferous stratigraphy and palæontology in South Wales.

\section{Institution of Electrical Engineers: Awards}

The following have been elected to honorary membership of the Institution of Electrical Engineers : Sir Thomas Purves, for his distinguished work in electrical engineering, and his services to the Institution, of which he was president in 1929; and Admiral Sir John Cunningham, First Sea Lord and Chief of the Naval Staff, in recognition of the outstanding part played by him in stimulating the application of electrical techniques in the Royal Navy and the contributions made by officers of the Royal Navy to the applications and development of electrical science and engineering.

The Faraday Medal of the Institution of Electrical Engineers has been awarded to Prof. M. L. E. Oliphant, Poynting professor of physics in the University of Birmingham, for his distinguished work in nuclear physics and his original discoveries in the physical sciences, particularly in the realm of electromagnetic oscillations, their production, study and use. The Faraday Medal is awarded by the Council of the Institution, not more frequently than once a year, either for notable scientific or industrial achievement in electrical engineering, or for conspicuous service rendered to the advancement of electrical science without restriction as regards nationality, country of residence, or membership of the Institution.

\section{Industrial Research in East Africa}

THE report of the East African Industrial Research Board for the year ended December 31, 1946 (Nairobi. 1s. $6 d$.$) , includes the report of the acting chairman,$ Mr. H. B. Stant, and separate reports on the progress of the main research projects. The most important of these for agriculture in East Africa is the calcina- 